\title{
Molecular characterization of Ichtyobronema hamulatum (Moulton, 1931) (Nematoda: Quimperiidae), a common parasite of burbot Lota lota (Linnaeus) (Actinopterygii: Lotidae)
}

\author{
S. G. SOKOLOV, S. V. MALYSHEVA*
}

Centre of Parasitology, A.N. Severtsov Institute of Ecology and Evolution, Russian Academy of Sciences, Leninskii prospect, 33, Moscow, 119071, Russian Federation, E-mail: sokolovsg@mail.ru, "malysheva24@gmail.com

Article info

Received January 30, 2017 Accepted April 19, 2017

\begin{abstract}
Summary
The phylogenetic analysis of partial SSU, LSU (rDNA) and COI (mtDNA) sequences was performed for the quimperiid nematode Ichtyobronema hamulatum, a common parasite of the burbot Lota lota. The study of SSU (for 2007 bp long alignment) has shown that in all kinds of analyses I. hamulatum cluster with Paraquimperia africana (Quimperiidae), while another quimperiid, Paraseuratum sp., unites in a separate clade with Spectatus spectatus (Kathlaniidae). Both groups do not form direct phylogenetic links with the rest of seuratoid nematodes (i.e. Cucullanidae and Seuratidae). Obtained data (for $1080 \mathrm{bp}$ long alignment) exhibit the phylogenetic affinity of $I$. hamulatum and $P$. africana with kathlaniids of the genus Falcaustra. The analysis of LSU sequences has revealed that I. hamulatum occupies the basal position in relation to all other members of Spirurina and Rhabditina.
\end{abstract}

Keywords: Ichtyobronema; Lota; Nematoda; phylogeny

\section{Introduction}

Ichtyobronema hamulatum (Moulton, 1931) Moravec, 1994, the only representative of the genus, is a parasitic nematode characterized by the Holarctic distribution. It occurs mostly in lotid fishes (Arthur \& Margolis, 1975; Moravec, 1994), but it was also recorded from freshwater scorpeniform fishes and representatives of some other fish taxa in some parts of the geographic range (in particular, in Lake Baikal) (Zaika, 1965). Over the years, this nematode has been reported under different names as: Ichtyobronema conoura (Linstow, 1885), Ichtyobronema gnedini Sudarikov et Ryzhikov, 1952, Haplonema hamulatum Moulton, 1931, Cottocomephoronema hamulatum (Moulton, 1931) and Cottocomephoronema problematica Layman, 1933 (Gnedina \& Savina, 1930; Sudarikov \& Ryzhikov, 1952; Trofimenko, 1974; Arthur \& Margolis, 1975). Arthur \& Margolis (1975) proposed the synonymy of all the names used which was accepted by subsequent authors (Chabaud, 1978; Fagerholm, 1982; Vismanis et al., 1987; Moravec, 1994; Sokolov,
2004). According to Arthur \& Margolis (1975), the species in question belonged to the genus Haplonema Ward \& Magath, 1917 as $H$. hamulatum Moulton, 1931. Later, $H$. hamulatum was soundly transferred to the re-established genus Ichthyobronema [sic] Gnedina et Savina, 1930 as Ichthyobronema hamulatum (Moulton, 1931) (see Moravec, 1994; Sokolov, 2004). The original spelling Ichtyobronema (see Gnedina \& Savina, 1930) was changed to Ichthyobronema in accordance with the grammatical rules of the Latinization of the words of Greek origin (Chabaud et al., 1959). This amended version has been accepted by many authors including Moravec (1994) and Sokolov (2004). However, as follows from the Articles 32.3 and 32.5 .1 of the $4^{\text {th }}$ edition of the International Code of Zoological Nomenclature, the name correction made by Chabaud et al. (1959) should be considered as "an unjustified emendation". Herein, we propose to return to the original spelling 'Ichtyobronema' with following names considered as junior synonyms: Ichthyobronema [sic] Gnedina et Savina, 1930, Cottocomephoronema Layman, 1933 and Haplonema Ward et Magath, 1917

\footnotetext{
${ }^{*}$ - corresponding author
} 
sensu Arthur \& Margolis, 1975 pro parte. A molecular phylogenetic analysis of I. hamulatum based on partial SSU rDNA, LSU rDNA and COI mtDNA sequences was performed.

\section{Materials and Methods}

Isolation and morphological observation of nematodes

Specimens of $I$. hamulatum were recovered from the intestine of Lota lota (Linnaeus, 1758), caught in March 2013 in the Onega Lake near the city of Petrozavodsk, Russia (coordinates: $61^{\circ} 49^{\prime} \mathrm{N}$ and $34^{\circ} 24^{\prime} \mathrm{E}$ ). Nematodes were fixed in $4 \%$ formaldehyde and processed to glycerol. Some specimens were frozen for further molecular analysis. Species affiliation of the parasites was diagnosed by morphological features studied with the aid of light microscope Axio Imager A1 (Zeiss AG, Oberkochen, Germany).

\section{Molecular profiles}

Nematode specimens were kept at $-18^{\circ} \mathrm{C}$ prior to DNA extraction. The DNA was extracted according to Holterman et al. (2006). The worm-lysis solution was prepared immediately before DNA extraction containing $950 \mu \mathrm{l}$ of mixture of $2 \mathrm{ml}$ of $1 \mathrm{M} \mathrm{NaCl}, 2 \mathrm{ml}$ of $1 \mathrm{M}$ Tris- $\mathrm{HCl}(\mathrm{pH} 8)$ plus $5.5 \mathrm{ml}$ of deionized water plus $10 \mu \mathrm{l}$ of mercaptoethanol and $40 \mu \mathrm{l}$ of proteinase $\mathrm{K}(20 \mathrm{mg} / \mathrm{ml})$. Single nematodes were transferred to $25 \mu$ of sterile water and after addition of $25 \mu$ of worm-lysis solution each tube was incubated at $65^{\circ} \mathrm{C}$ for $90 \mathrm{~min}$. The tubes with homogenate were then incubated at $99{ }^{\circ} \mathrm{C}$ for $5 \mathrm{~min}$ to deactivate proteinase $\mathrm{K}$ and $0.8-1.2 \mu \mathrm{l}$ of homogenate was used as PCR template.

PCR reactions were performed using Encyclo Plus PCR kit (Evrogen $\AA$, Moscow, Russia) according to the manufacturer's manual. Primer pairs LSU391 (5'-AGC GGA GGA AAA GAA ACT AA-3') and LSU501 (5'-TCG GAA GGAACC AGC TAC TA-3') were used to amplify D2-D3 expansion segment of LSU rDNA fragment (Nadler et al., 2006). PCR cycling parameters included primary denaturation at $94{ }^{\circ} \mathrm{C}$ for 3 min followed by 34 cycles $94{ }^{\circ} \mathrm{C}$ for $30 \mathrm{~s}$, $52{ }^{\circ} \mathrm{C}$ for $30 \mathrm{~s}$ and $72^{\circ} \mathrm{C}$ for $1 \mathrm{~min}$, followed by post-amplification extension at $72^{\circ} \mathrm{C}$ for $7 \mathrm{~min}$.

Two pairs of primers were used to amplify SSU rDNA. A pair of nematode-specific primers nem18SF (5'-CGC GAA TRG CTC ATT ACA ACA GC-3') and nem18SR (5'-GGG CGG TAT CTG ATC GCC-3') was used to amplify 5' portion of SSU rDNA (Floyd et al., 2005). PCR cycling parameters included primary denaturation at $95^{\circ} \mathrm{C}$ for $5 \mathrm{~min}$ followed by 5 cycles of $94^{\circ} \mathrm{C}$ for $30 \mathrm{~s}, 47^{\circ} \mathrm{C}$ for $30 \mathrm{~s}$ and $72{ }^{\circ} \mathrm{C}$ for $40 \mathrm{~s}$ and 35 cycles of $94^{\circ} \mathrm{C}$ for $25 \mathrm{~s}, 54^{\circ} \mathrm{C}$ for $30 \mathrm{~s}$ and $72^{\circ} \mathrm{C}$ for $40 \mathrm{~s}$, followed by post-amplification extension at $72{ }^{\circ} \mathrm{C}$ for $5 \mathrm{~min}$. Another pair 24F (5'-AGR GGT GAAATY CGT GGA CC-3') and Q39 (5'-TAA TGA TCC WTC YGC AGG TTC ACC TAC-3') was used to obtain remaining 3' end of SSU rDNA (Blaxter et al., 1998). PCR cycling parameters included primary denaturation at $95{ }^{\circ} \mathrm{C}$ for $5 \mathrm{~min}$ followed by 35 cycles of $94{ }^{\circ} \mathrm{C}$ for $60 \mathrm{~s}$, $53^{\circ} \mathrm{C}$ for $90 \mathrm{~s}$ and $72{ }^{\circ} \mathrm{C}$ for $90 \mathrm{~s}$, followed by post-amplification extension at $72^{\circ} \mathrm{C}$ for $6 \mathrm{~min}$.
PCR reaction products were visualized in agarose gel and bands were excised for DNA extraction with Wizard $^{\circledR}$ SV Gel and PCR Clean-Up System (Promega ${ }^{\circledR}$, Madison, USA). Samples were directly sequenced using same primers as used for primary PCR reactions.

Nematode sequences obtained during this study have been deposited in GenBank NCBI (https://www.ncbi.nlm.nih.gov/) as: KY476350 for D2-D3 LSU rDNA and KY476351 for SSU rDNA.

For comparative purposes and phylogeny construction some sequences from GenBank were also used, including the mitochondrial cytochrome c oxidase subunit I (COI) gene sequence for I. hamulatum obtained earlier (Malysheva et al., 2016). The SSU rDNA sequence for Quimperia sp. (DQ813448) (Seuratoidea: Quimperiidae) was not included in the analysis due to its short length.

Sequence alignments were generated using Clustal X (Thompson et al., 1997) under default values for gap opening and gap extension penalties. MEGA 5.2 (Tamura et al., 2011) was used for the search of proper model of evolution and to obtain phylogenies based on maximum parsimony (MP), maximum likelihood $(\mathrm{ML})$ and neighbour joining (NJ) methods. Modeltest 3.7 (Posada \& Crandall, 1998) was also used to find the optimal model of evolution using the Akaike information criterion. PAUP* $4.0 \mathrm{~b} 10$ (Swofford, 1998) was used to calculate the level of nucleotide differences. Mr Bayes v3.2.1. (Ronquist et al., 2012) was used for Bayesian analysis (Bayesian Inference $-\mathrm{BI}$ ). Bayesian analyses were run $2 \times 10^{6}$ generations under $\mathrm{GTR}+\mathrm{G}+$ I model using relative burn-in (discarding the first $25 \%$ of samples). Average standard deviation of split frequencies at the end of the analyses was lower than 0.01. Tracer v1.3 (Rambaut \& Drummond, 2007) was used to estimate convergence statistics

\section{Results}

The phylogenetic analysis of the partial SSU rDNA sequence of I. hamulatum (for $2007 \mathrm{bp}$ long alignment) carried out by different methods (MP, ML, NJ and BI) has shown that in all obtained cladograms the species studied united with the African representative of the family Quimperiidae, Paraquimperia africana Moravec, Boomker et Taraschewski, 2000 from freshwater eels, in a separate clade with the high level of support (Figure 1, A). At the same time, another representative of the family, Paraseuratum sp. from erythrinid fish Hoplias microlepis (Günther, 1864), united in a separate clade with Spectatus spectatus Travassos, 1923 (Kathlaniidae; Cosmocercoidea), a parasite of South American characins and catfishes, with the high level of support. In any kind of analysis, both clades never merged with each other as well as with the $\mathrm{Cu}$ cullanidae (Seuratoidea) occupying the outer position in relation to other members of Spirurina sensu De Ley \& Blaxter, 2002, including Cruzia americana Maplestone, 1930 (Kathlaniidae; Cosmocercoidea) and Linstowinema sp. (Seuratoidea; Seuratidae).

We have also performed the phylogenetic analysis based on the partial SSU rDNA data (for 1080 bp long alignment) in addition 
A

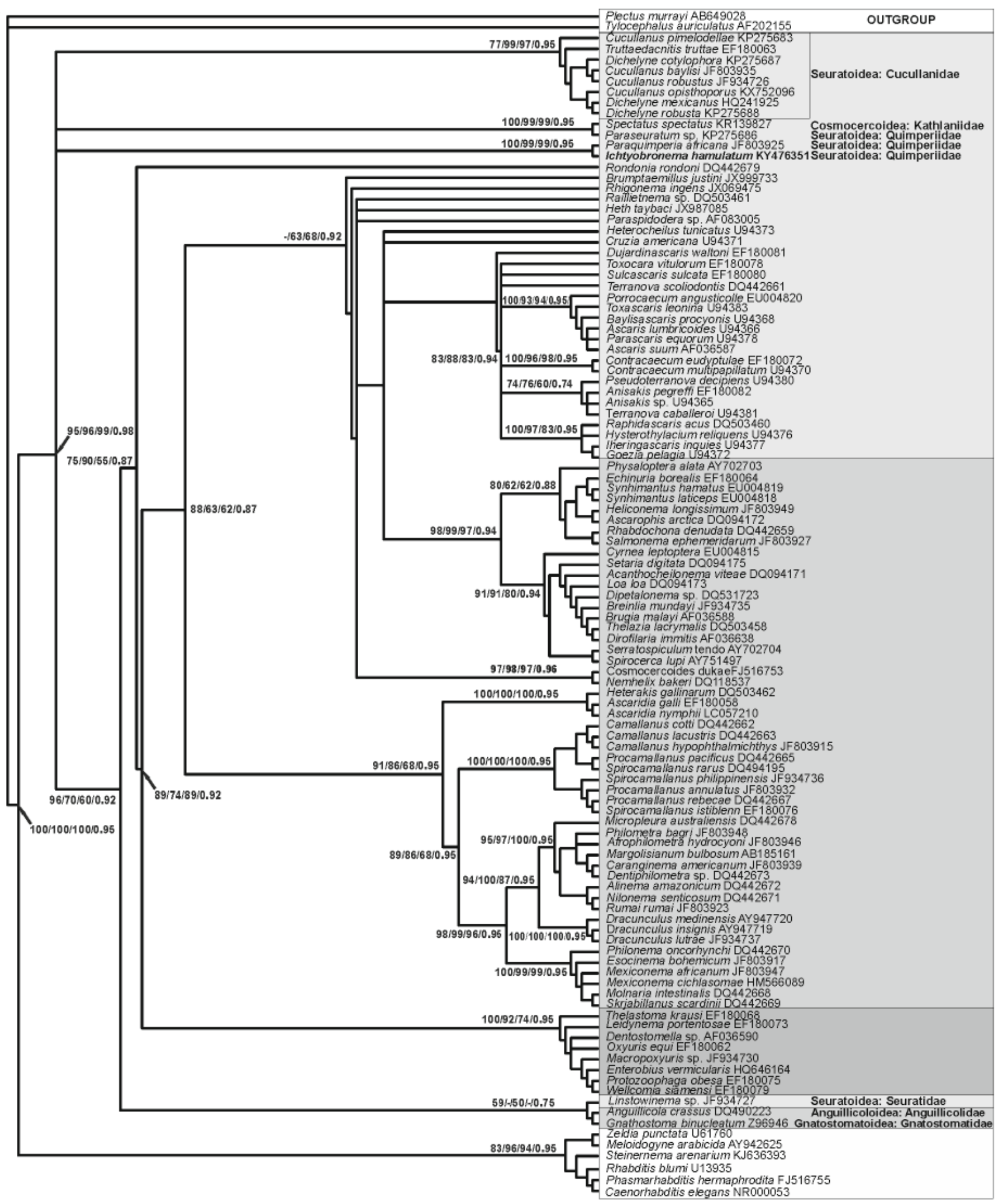




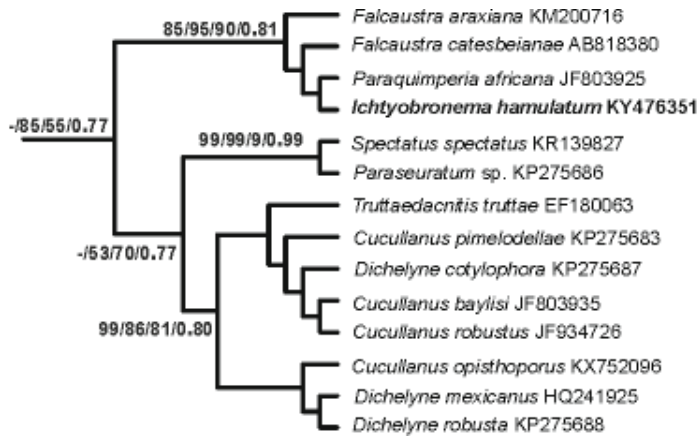

Fig. 1. Phylogenetic relationships of Ichtyobronema hamulatum (Moulton, 1931) inferred from analysis of SSU rDNA. A: MP analysis; 2007 bp long alignment; B: part of the MP cladogram; $1080 \mathrm{bp}$ long alignment. The bootstrap/posterior probability values are given near nodes for MP/ML/NJ/BI methods of analyses, respectively. Newly obtained sequence is marked in bold. Major clades are highlighted by shaded or plain boxes.

comprising other representatives of the family Kathlaniidae (Dacnitoides sp., Falcaustra araxiana Massino, 1924 and Falcaustra catesbeianae Walton, 1929) that were not included in the previous analysis due to its shorter sequence length. Analysis has revealed that $I$. hamulatum and $P$. africana clustered with two representatives of the genus Falcaustra Lane, 1915 parasitizing in frogs and freshwater turtles in all methods of analysis but with the different level of support, while Paraseuratum sp. and S. spectatus united with cucullanids forming a sister group with the low level of support (Figure 1, B). At the same time, two other representatives of Kathlaniidae ( $C$. americana and Dacnitoides sp.) were in the group Ascaridomorpha and Rhigonematomorpha (not shown).

An analysis of nucleotide differences in the partial SSU rDNA sequences (for $1080 \mathrm{bp}$ long alignment) between representatives of Kathlaniidae and Quimperiidae showed that I. hamulatum differed from $P$. africana and $F$. catesbeianae in $2 \mathrm{bp}$, while for $S$. spectatus and Paraseuratum sp. this difference was $25 \mathrm{bp}$ and $31 \mathrm{bp}$, respectively.

The phylogenetic analysis based on D2-D3 LSU rDNA sequences for I. hamulatum (the only LSU data available for Quimperiidae) has shown that in all obtained cladograms I. hamulatum occupies the basal position in the out-group level in relation to all other members of Spirurina and Rhabditina. The phylogenetic position of the species studied based on COI mtDNA data was hampered due to the high fragmentation of the data presented in the NCBI GeneBank that did not allow to obtain an alignment of the acceptable length (i.e. more than $300 \mathrm{bp}$ ) and the lack of data for other quimperiids and kathlaniids.

\section{Discussion}

Allocation of the genus Ichtyobronema to a particular family has been discussed in the literature (Gnedina \& Savina, 1930; Skrjabin, 1946; Sudarikov \& Ryzhikov, 1952; Chabaud et al., 1959; Yamaguti, 1961; Roytman, 1963; Inglis, 1967; Ivashkin \& Khromova, 1976; Chabaud, 1978). Currently, the opinion of Inglis (1967) based on the morphology and supporting the species affinity to the Quimperiidae is generally accepted (Moravec, 1994; Sokolov,
2004). Our molecular data justify the placement of the genus in Quimperidae (Fig.1, A).

In the majority of systems of Nematoda proposed in the last few decades, the hypothesis of Inglis (1967) on the close relationships between quimperiids, cucullanids and seuratids was accepted thus allowing to place these groups of parasites (in combination with some other families) in the superfamily Seuratoidea (Chabaud, 1978; Maggenti, 1981; De Ley \& Blaxter, 2004; Hodda, 2011). Regardless of Inglis (1967), the idea of the phylogenetic affinity of the nematode groups mentioned, but in a different taxonomic design, was suggested by Le-Van-Hoa \& Phan-Ngoc-Khue (1967). According to Chabaud (1978) and Baker (1980), the Seuratoidea is phylogenetically related to Cosmocercoidea, while Quimperiidae and Kathlaniidae occupy intermediate position between them. This point of view has developed on the basis of Baylis's (1930) views about the phylogenetic affinity of quimperiids and kathlaniids. Unlike most authors, Skrjabin \& Ivashkin (1968a) considered Seuratoidea to be a polyphyletic group and allocated its constituent families and subfamilies to different superfamilies and suborders of the orders Spirurida and Rhabditida. They placed Quimperiidae and Cucullanidae into the superfamily Cucullanoidea of the suborder Cucullanata (see Skrjabin \& Ivashkin, 1968a; 1968b). Ryzhikov \& Sonin (1981) partially supported the opinion of Skrjabin \& Ivashkin (1968a) and removed Cucullanidae from Seuratoidea. For Seuratoidea, Ryzhikov \& Sonin (1981) have accounted three families only: Seuratidae, Schneidernematidae and Quimperiidae.

In the present study, the phylogenetic analysis based on partial SSU sequences (2007 bp long alignment) has shown that Quimperiidae is not a monophyletic group and does not form clear direct phylogenetic connections with Cucullanidae and Seuratidae (Figure 1, A). Similar results have been demonstrated in the studies of Černotíková et al. (2011) and Choudhury \& Nadler (2016). Data obtained also point out to the phylogenetic affinity of the studied species and another representative of the family $(P$. africana) with kathlaniids of the genus Falcaustra. Similar results in analysis using the only one representative of quimperiids (i.e. P. africana) were obtained by Rajabloo et al. (2016). In both cases, quimperiids clustered with Falcaustra representatives forming a 
sister clade with Cucullanidae representatives with the low level of support (NJ bootstrap value for $60 \%$ in Rajabloo et al., 2016 study) (Fig.1, B). In addition, our data support the conclusions of Pereira et al. (2015) and Rajabloo et al. (2016) on the polyphyly of Kathlaniidae. Separated from other qumperiids, the position of Paraseuratum sp. in obtained cladograms can be supported by certain morphological arguments. This parasite was found in Panama (Choudhury \& Nadler, 2016) and, therefore, belongs to the South American pool of species of this genus. According to Petter (1987), morphologically, the South American members of the genus Paraseuratum Johnston et Mawson, 1940 occupy an intermediate position between quimperiids and cucullanids of the subfamily Campanarougetinae.

The present study together with the published data show that so far, the phylogenetic relationships between Quimperiidae and Cucullanidae cannot be reliably resolved and more data including a variety of representatives of these taxa are needed.

\section{Acknowledgements}

The research was supported by grant № 17-04-00095a from the Russian Foundation of Basic Researches and the research program "Bioresources" from the Russian Academy of Sciences. Authors are grateful to Dr S.E. Spiridonov and E.S. Ivanova from the Laboratory of Taxonomy and Evolution of Parasites (IPEE RAS) for their professional consultation and critical review of the manuscript.

\section{References}

ARthUR, J.R., MARgolis, L. (1975): Revision of the genus Haplonema Ward and Magath, 1917 (Nematoda: Seuratoidea). Can. J. Zool., 53: 736 - 747. DOI: 10.1139/z75-088

BAKER, M.R. (1980): Reclassification of Oxysomatium inglisi Anderson, 1964 and Aplectana gigantica Olsen, 1938 (Nematoda: Cosmocercoidea) from North American frogs. Syst. Parasitol., 1: 245 - 253. DOI: 10.1007/BF00009850

BAYLIS, H.-A. (1930): Mission Saharienne, Augiêras-Draper 19271928. Parasitic Nematodes. Bull. Mus. Hist. Nat. (ser. 2.), 2: 117 $-130$

Blaxter, M.L., De Ley, P., Garey, J.R., Liu, L.X., Scheldemann, P., Vierstraete, A., Vanfleteren, J.R., Mackey, L.Y., Dorris, M., Frisse, L.M., VIDA, J.T., ThomAs, W.K. (1998): A molecular evolutionary framework for the phylum Nematoda. Nature, 392: 71 - 75. DOI: 10.1038/32160

Černotíková, E., Horák, A., Moravec, F. (2011): Phylogenetic relationships of some spirurine nematodes (Nematoda: Chromadorea: Rhabditida: Spirurina) parasitic in fishes inferred from SSU rRNA gene sequences. Folia Parasitol., 58: 135 - 148. DOI: 10.14411/ fp. 2011.013

Chabaud, A.G. (1978): Keys to genera of the superfamilies Cosmocercoidea, Seuratoidea, Heterakoidea and Subuluroidea. In: Anderson, R.C., Chabaud, A.G., Willmott S. (Eds). CIH Keys to the
Nematode Parasites of Vertebrates. Vol. 6. Wallingford, Commonwelth Agric. Bureaux Inlernal, pp. 1 - 71

Chabaud, A.G., Campana-Rouget, Y., Brygoo, E.R. (1959): Les Nématodes Seuratoidea nov. sup. fam. et l'origine des Spirurida. C. R. Hebd. Seances Acad. Sci., 248: 1449 - 1451

Choudhury, A., Nadler, S.A. (2016): Phylogenetic relationships of Cucullanidae (Nematoda), with observations on Seuratoidea and the monophyly of Cucullanus, Dichelyne and Truttaedacnitis. J. Parasitol., 102: 87 - 93. DOI: 10.1645/15-806

De Ley, P., Blaxter, M.L. (2004): A new system for Nematoda: combining morphological characters with molecular trees, and translating clades into ranks and taxa. Nematology Monographs and Perspectives, 2: $633-653$

FAgerholm, H.-P. (1982): Parasites of fish in Findland. VI. Nematodes. Acta Acad. Aboensis. Ser. B., 40: 1 - 128

GnedINA, M.P., SAVINA, N.V. (1930): On the fauna of parasitic worms of fishes of the North Dvina River basin. In: SKYABIN, K.I. (Ed). Raboty 32 i 38 Soyuznykh gel'mintologicheskikh ekspeditsii na territorii Severo-Dvinskoy gubernii v 1926 i 1927 godakh [Works of the 32nd and 38th Union helminthological expeditions in the territory of the North-Dvinsky province in 1926 and 1927 years]. Vyatka: Severo-Dvinskiy GubZdrav and GubVetOtdel, pp. 87 - 106. (In Russian) HoddA, M. (2011). Phylum Nematoda Cobb 1932. In: Zhang, Z.-Q. (Ed) Animal biodiversity: An outline of higher-level classification and survey of taxonomic richness. Zootaxa, 3148: 63 - 95.

DOI: 10.11646/zootaxa.3703.1.13

Holterman, M., van der Wurff, A., van den Elsen, S., van Megen, H., Bongers, T., Holovachov, O., Bakker, J., Helder, J. (2006): Phylum-wide analysis of SSU rDNA reveals deep phylogenetic relationships among nematodes and accelerated evolution towards crown clades. Mol. Biol. Evol., 23: 1792 - 1800. DOI: 10.1093/ molbev/msl044

INGLIS, W.G. (1967): The relationships of the nematode superfamily Seuratoidea. J. Helminthol., 41: 115 - 136. DOI: https://doi. org/10.1017/S0022149X00021544

IVASHKIN, V.M., KHROMOVA, L.A. (1976): Cucullanata and Gnathostomatata of animals and man and the diseases caused by them. Osnovy Nematodologii. Vol. 27. Moscow: Nauka, 436 pp. (In Russian)

Le-Van-Hoa, Phan-Ngoc-Khue (1967): Relation entre les Seuratoidea et les Cucullanidae par l'intermediaire d'un nouveau nematode Campanarougetia campanarougetae n. g., n. sp., parasite des anguilles du sud Viet-Nam [Relationship between Seuratoidea and Cucullanidae via a new nematode Campanarougetia campanarougetae n. g., n. sp., a parasite of eels from southern Viet-Nam]. Bull. Soc. Pathol. Exot., 60: 393 - 398 (In French)

Maggenti, A. (1981): General Nematology New York: Springer-Verlag, $373 \mathrm{pp}$.

MalysheVA, S.V., EfeYkin, B.D., Teterina, A.A. (2016): A new primer set for amplification of COI mtDNA in parasitic nematodes. Russ. J. Nematol., 24: 73 - 75

MoRAvec, F. (1994): Parasitic nematodes of freshwater fishes of Europe. Praha: Academia, $474 \mathrm{pp}$. 
Nadler, S.A., Bolotin, E., Stock, S.P. (2006): Phylogenetic relationships of Steinernema Travassos, 1927 (Nematoda: Cephalobina: Steinernematidae) based on nuclear, mitochondrial and morphological data. Syst. Parasitol., 63: 161 - 181. DOI: 10.1007/ s11230-005-9009-3

Pereira, F.B., Tavares, L.E.R., Paiva, F., Scholz, T., Luque, J.L. (2015): A morphological and molecular study of Spectatus spectatus (Kathlaniidae), including redescription of the species and amendment of genus diagnosis. J. Parasitol. 101: $468-475$.

DOI: 10.1645/15-764.1

Petter, A.J. (1987): Nematodes de poisons de l'Equateur. Rev. Suisse Zool., 94: 61 - 76

Posada, D., Crandall, K.A. (1998): Modeltest: Testing the model of DNA substitution. Bioinformatics 14: $817-818$

Rambaut, A., Drummond, A.J. (2007): Tracer v1.4. [computer software]. Retrieved October 4, 2016 from: http://tree.bio.ed.ac.uk/ software/tracer

RajabloO, M., Sharifiyazdi, H., Namazi, F., Shayegh, H., RakhshanDEHROO, E., FARJANIKISH, G. (2016): Morphological and molecular analyses of the spiruroid nematode, Falcaustra araxiana Massino, 1924 (= Spironoura araxiana) from the European pond turtle (Emys orbicularis). J. Helminthol. DOI: 10.1017/S0022149X16000195

Ronquist, F., Teslenko, M., van der Mark, P., Ayres, D.L., Aaron, D., Höhna, S., Larget, B., Liu, L., Suchard, M.A., Huelsenbeck, J.P. (2012): MrBayes 3.2: efficient Bayesian phylogenetic inference and model choice across a large model space. Syst. Biol., 61: 539 - 542. DOI: 10.1093/sysbio/sys029

Rortman, V.A. (1963): Nematodes of fishes from the Zeya River basin. Trudy Gel'mintol. Lab. 13: 253 - 300 (In Russian)

RYZHIKov, K.M, SonIN, M.D. (1981): A system of nematodes - parasites of vertebrate animals. Parazitologiya, 15: 510 - 518 (In Russian)

SkRJABIN, K.I. (1946) A new review of systematics of Spirurata (Nematoda) parasitic in fishes. Dokl. Akad. Nauk SSSR. 54: 755 - 756 (In Russian)

SKRJABIN, K.I., IVASHKIN, V.M. (1968a): On the problem of eliminating superfamily Seuratoidea Chabaud, Campana-Rouget et Brygoo, 1959, within the system of nematodes. Izvestiya Akad. Nauk SSSR, Ser. Biologicheskaya 6: 789 - 792 (In Russian)
SKRJABIN, K.I., IVASHKIN, V.M. (1968b): Evolution of parasitic nematodes of the subclass Secernentea in ecological aspect. Trudy Gel'mintol. Lab. 19: 169 - 185 (In Russian)

SokoLov, S.G. (2004): On the validity of the genus Ichthyobronema Gnedina et Savina, 1930 (Nematoda, Spirurida: Quimperiidae). Parazitologiya, 38: 257 - 260 (In Russian)

SudARIKOV, V.E., RYZHIKOV, K.M. (1952): Establishment of a new family of nematodes from freshwater fishes (Spirurata: Haplonematidae nov. fam.). Trudy Gel'mintol. Lab. 6: 152 - 157 (In Russian)

Swofford, D.L. (1998): PAUP*: Phylogenetic Analysis Using Parsimony (and other methods). Version 4.0b10 [computer software]. Sunderland, MA: Sinauer Associates.

Tamura, K., Peterson, D., Peterson, N., Stecher, G., Nei, M., KuMAR, S. (2011): MEGA5: molecular evolutionary genetics analysis using maximum likelihood, evolutionary distance, and maximum parsimony methods. Mol. Biol. Evol. 28: 2731 - 2739. DOl: 10.1093/molbev/msr121

Thompson, J.D., Gibson, T.J., Plewniak, F., Jeanmougin, F., Higgins, D.G. (1997): The ClustalX windows interface: flexible strategies for multiple sequence alignment aided by quality analysis tools. Nucleic Acids Res., 24: 4876 - 4882. DOI: 10.1093/nar/25.24.4876

TROFImENKo, V.Y. (1974): New data on nematodes of the genera Cottocomephoronema and Comephoronerna, parasites of burbot. Trudy Gel'mintol. Lab. 24: 199 - 207 (In Russian)

Vismanis, K.O., Lomakin, V.V., Roytman, V.A., Semenova, M.K., TroFIMENKO, V.Y. (1987): Phylum Nemathelminthes. In: BAUER, O.N. (Ed). Opredelitel' parazitov presnovodnykh ryb fauny SSSR [The key for the identification of freshwater fish parasites of the USSR fauna]. T. 3. Leningrad: Nauka, pp. 199 - 310 (In Russian) YamagutI, S. (1961): Systema Helminthum. Vol. III. The nematodes of vertebrates. Part 1. New York: Interscience Publishers, 679 pp. ZAIKA, V.E. (1965): The parasite fauna of fishes of Lake Baikal. Moscow: Nauka, 106 pp. (In Russian)

The Nucleotide Database of National Center for Biotechnology Information, U.S. National Library of Medicine. Retrieved November 25, 2016 from https://www.ncbi.nlm.nih.gov 